\title{
Competition of Squirreltail with Cheatgrass at Three Nitrogen Levels*
}

\author{
Allan R. Stevens' ${ }^{1 \#, ~ V a l ~ J o ~ A n d e r s o n ², ~ R a c h e l ~ F u g a l 2 ~}$ \\ ${ }^{1}$ Department of Biology, Snow College, Ephraim, USA \\ ${ }^{2}$ Plant and Wildlife Sciences, Brigham Young University, Provo, USA \\ Email: "allan.stevens@snow.edu
}

Received 24 January 2014; revised 25 February 2014; accepted 7 March 2014

Copyright (C) 2014 by authors and Scientific Research Publishing Inc.

This work is licensed under the Creative Commons Attribution International License (CC BY). http://creativecommons.org/licenses/by/4.0/

(c) (i) Open Access

\section{Abstract}

Squirreltail (Elymus elymoides [Raf] Swezey) can grow in cheatgrass (Bromus tectorum L.) stands, and has reduced the biomass production of cheatgrass in its immediate vicinity. A field experiment was conducted to determine: 1) if competition for nitrogen resources occurs between seedlings of squirreltail and seedlings of cheatgrass, under low, medium, and high nitrogen levels, and; 2) if competition for nitrogen resources in the seedling stage is a mechanism that allows squirreltail to establish in cheatgrass stands. Five accessions of squirreltail were each seeded with a single accession of cheatgrass in a cultivated field near Ephraim, Utah in the fall of 1995 and again in 1996. A completely randomized strip-plot design with 3 replications was used including the 5 joint seedings as well as pure seedings of each accession of both species. Three nitrogen levels representing high, medium (control), and low were applied. The study was replicated over 2 years in different areas of the same field. Harvests of above-ground biomass of squirreltail and cheatgrass within each treatment were conducted in July of 1996 and 1997. Using biomass production as a measure of efficient nitrogen use, cheatgrass competed for and used nitrogen resources more efficiently than squirreltail when nitrogen was not limiting. All squirreltail accessions were able to compete for and use nitrogen more efficiently than cheatgrass when there was low availability of nitrogen. Some accessions of squirreltail competed for nitrogen resources more efficiently than others both in the control and at the reduced nitrogen level. White Rocks and Sublette squirreltail accessions were the best competitors with cheatgrass at the low nitrogen level reducing the cheatgrasss biomass by as much as $75 \%$ and $67 \%$ respectively. An intermediate competitor with cheatgrass was the Gunnison accession. The Washakie and Pueblo accessions were poor competitors with cheatgrass at low nitrogen levels.

\section{Keywords}

Accession; Biomass; Bromus tectorum; Elymus elymoides; Seedling

\footnotetext{
${ }^{*}$ At the time of the research, the senior author was a graduate student, Brigham Young University, Provo, UT.

\#Corresponding author.
} 


\section{Introduction}

Cheatgrass (Bromus tectorum L.), an introduced annual from Eurasia, has spread over millions of acres of western North America severely damaging range forage resources. This species is highly competitive for abundant resources and is well-adapted to the fire cycle it creates. It has been the subject of many research projects to find feasible ways to control it. Seeding desirable plants that can compete with it may be one tool to improve forage resources.

Competition in plant communities for limited resources is an important factor in successional dynamics [1][3]. In early seral stages, when nutrients are abundantly available, species adapted to utilizing resources quickly although less efficiently tend to dominate [4]-[6]. As succession proceeds and resources are tied up in the plant community, more efficient species are favored [7] [8]. Soil nitrogen is often a key resource involved [9] [10] and plants are not the only organisms competing for it. Decomposers play a critical role in nitrogen availability. As decomposer biomass increases, incorporated nitrogen increases, and thus the nitrogen available to plants reduces [11] [12].

Squirreltail (Elymus elymoides [Raf] Swezey) is a native, early to mid-successional, short-lived perennial bunchgrass [13]. It occurs on dry hills, plains, rocky slopes, and in open woods from South Dakota to British Columbia, South to Missouri, Texas, California, and Mexico. It has been reported from desert to montane and subalpine habitats, from 600 - $3500 \mathrm{~m}$ in elevation and exhibits tremendous ecotypic variation across its wide range of distribution [14]. It has been shown, when squirreltail is present in cheatgrass stands, it can reduce cheatgrass biomass production [15]. The effect of various levels of nitrogen availability on competition between these two critical species in arid and semiarid areas deserves more study. Certain ecotypes of squirreltail may be better competitors with cheatgrass than others.

The purpose of this study was to determine the effect of soil nitrogen availability during the fall and spring growth periods on the ability of different squirreltail accessions to establish and compete with cheatgrass. In order to manipulate nitrogen levels, we used fertilizer to increase available nitrogen and sucrose to decrease it. Introducing available carbon to the soil gives decomposers a rapid energy source for growing and utilizing nitrogen [16] [17].

\section{Methods}

The study site was located in a cultivated field on the Snow College Experimental Station near Ephraim, Sanpete County, Utah. The soil is a Woodrow silty, clay, loam (Xeric Torrifluvents) [18]. Seed of 5 squirreltail accessions were used in this study including selected accessions originally collected in: 1) Sublette County, Wyoming; 2) Pueblo, Pueblo County, Colorado; 3) Washakie County, Wyoming; 4) White Rocks in Skull Valley, Tooele County, Utah; and 5) Gunnison, Sanpete County, Utah. The cheatgrass seed used in this study was collected near Ephraim, Sanpete County, Utah.

A completely randomized split-plot design was established with $1651-\mathrm{m}^{2}$ plots in each of 3 strips. One of 3 different nitrogen levels was established in each strip separated by a 2-m tilled buffer. Nitrogen levels included: 1) added nitrogen established by the addition of $10 \mathrm{~g}$ of 34-0-0 ammonium nitrate $\cdot \mathrm{m}^{-2}$ applied 2 times a year in the fall and spring for a total of $20 \mathrm{~g} ; 2$ ) reduced nitrogen established by the addition of $53 \mathrm{~g}$ of sucrose $\cdot \mathrm{m}^{-2}$ applied in the late fall, early spring, and late spring for a total of $159 \mathrm{~g}$; and 3) control consisting of no nitrogen or sugar added. Within each nitrogen-treatment, 5 replications of the following seeding treatments were established in early fall of 1995 and repeated in 1996: 1) each of the 5 squirreltail accession were planted independently in 9 randomly selected plots at $0.1-\mathrm{m}$ intervals as a control for each squirreltail accession; 2) each of the 5 squirreltail accession were planted in 9 randomly selected plots at $0.1-\mathrm{m}$ intervals in association with cheatgrass seeds planted at the rate of 10,000 cheatgrass seeds $\cdot \mathrm{m}^{-2}$ to determine the competitive effects of cheatgrass and squirreltail; and 3) 9 plots were planted with 10,000 cheatgrass seeds $\cdot \mathrm{m}^{-2}$ to act as a control for cheatgrass. The plots were watered with 25 mm of water on 18 February 2007 and 15 March 2007 to reduce drought mortality.

All above-ground biomass in each plot was harvested at ground level by clipping in July of each year when cheatgrass plants were in the boot stage to ensure maximum above-ground biomass production by cheatgrass before seed shatter [19]. Plant material of cheatgrass and squirreltail were separated in the plots where they were planted together. Plant material was allowed to air dry and then weighed to determine above-ground dry weight biomass. Analysis of variance was used on each year independently to determine treatment significance. Data for each year and each strip plot were analyzed using the MSTAT-C statistical package [20]. 


\section{Results}

Precipitation varied between years. From October 1995-September 1996 there were only 291 mm of precipitation causing high mortality and low production for both squirreltail and cheatgrass. There were $397 \mathrm{~mm}$ of precipitation October 1996-September 1997 and even though biomass production was increased, the same trends occurred in treatment responses for both 1996 and 1997.

The control of each accession of squirreltail was compared orthogonally to the squirreltail grown with cheatgrass in both years. There were no significant differences between the control squirreltail plants and the squirreltail grown with cheatgrass in any of the accessions.

The squirreltail accession that competed best with cheatgrass in the reduced and medium nitrogen plots averaged across 1996 and 1997 was from White Rocks, Utah. It significantly reduced cheatgrass biomass production by 36\% in 1996 (Figure 1) and 75\% in 1997 (Figure 2) (p > 0.05). Biomass production of this accession was not significantly affected by cheatgrass at any nitrogen level either year (Figures 3 and 4).

A good competitor with cheatgrass in both years was the selected accession from Sublette County, Wyoming. In 1996 this accession significantly decreased the biomass production of cheatgrass the most in the low 67\% and medium 55\% nitrogen plots (Figure 1) ( $>$ > 0.05). Biomass production of this accession was higher than any of the other squirreltail accessions in 1996 (Figure 3). In 1997, when water was not a limiting factor, this accession

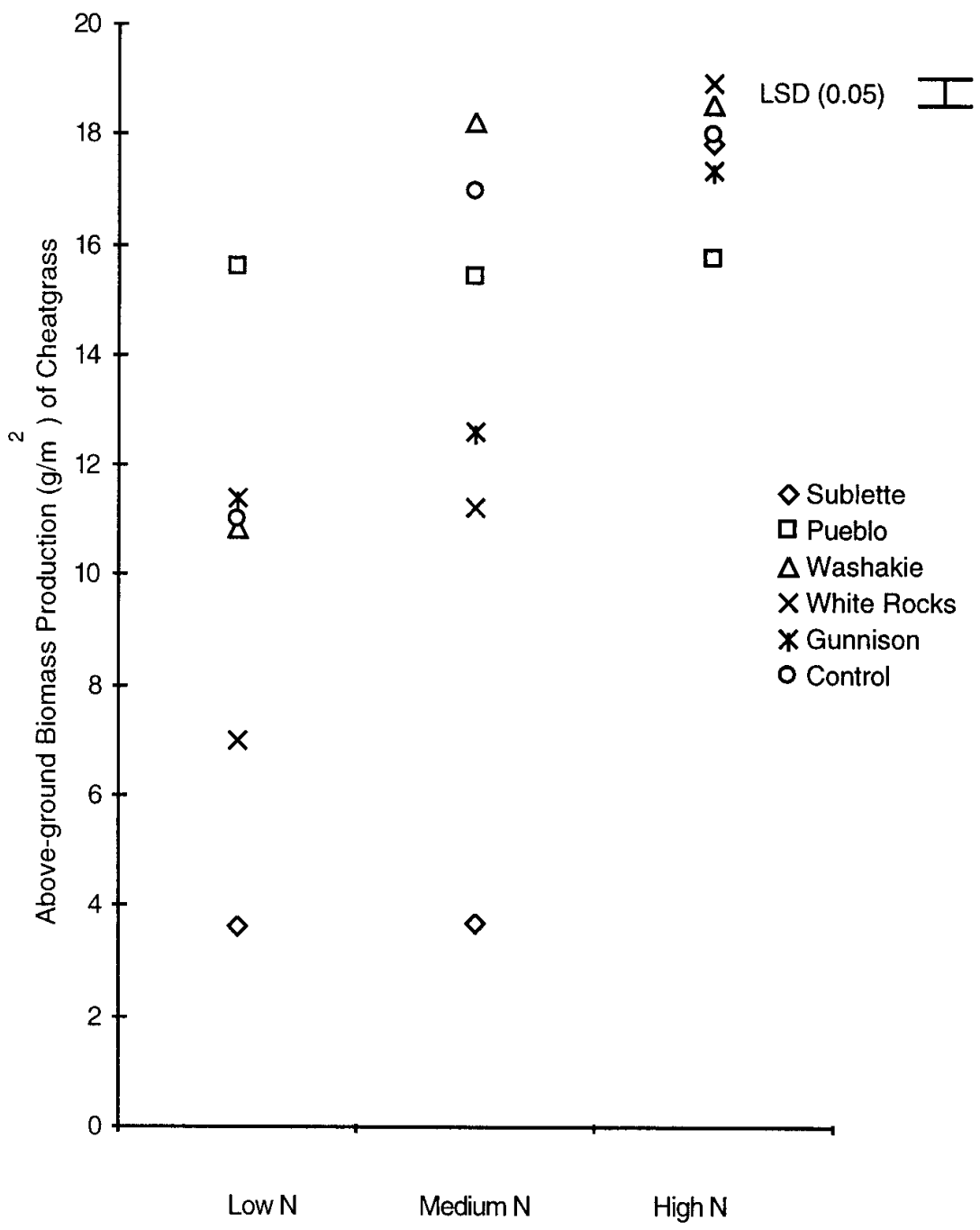

Figure 1. Above-ground biomass production $\left(\mathrm{g} \cdot \mathrm{m}^{-2}\right)$ of cheatgrass when grown alone (Control) or with 5 squirreltail accessions in a Low, Medium and High nitrogen treatment in 1996. 


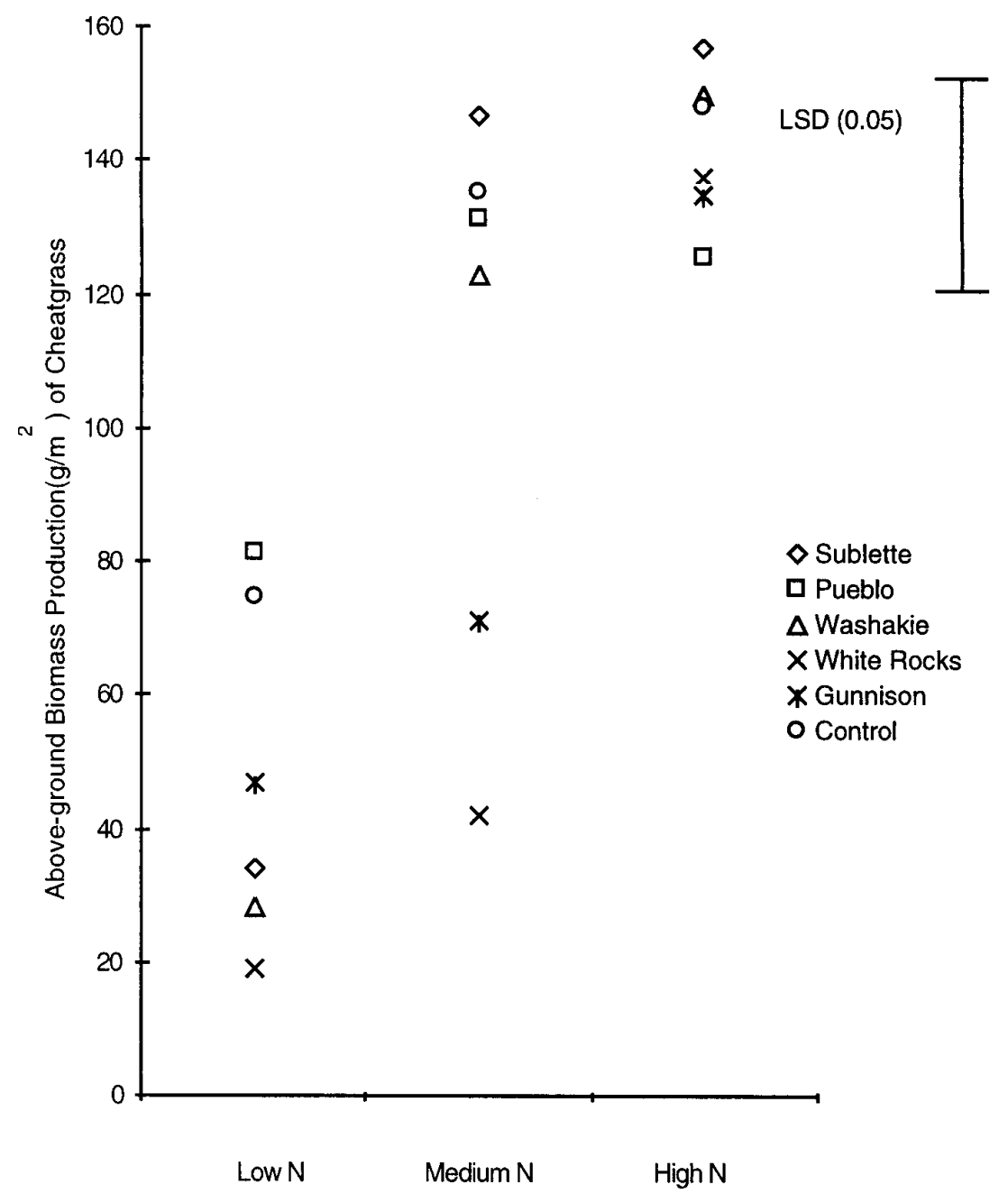

Figure 2. Above-ground biomass production $\left(\mathrm{g} \cdot \mathrm{m}^{-2}\right)$ of cheatgrass when grown alone (Control) or with 5 squirreltail accessions in a Low, Medium and High nitrogen treatment in 1997.

did not reduce the production of cheatgrass in the control treatment, but did reduce the production of cheatgrass in the low nitrogen treatment. In both years the biomass production of the Sublette County, Wyoming accession was significantly higher than most of the other accessions of squirreltail $(\mathrm{p}<0.05)$.

The Gunnison, Utah accession was an intermediate competitor with cheatgrass when compared to the other squirreltail accessions. In 1997, it reduced the biomass production of cheatgrass in both the low nitrogen treatment and in the control treatment. However, in 1996, it only reduced the biomass production of cheatgrass in the control treatment. Biomass production of the Gunnison accession was significantly higher than 2 of the other squirreltail accessions in both the low nitrogen treatment, and the control treatment in both years $(\mathrm{p}<0.05)$.

The selected Washakie County, Wyoming accession only decreased cheatgrass biomass production significantly in 1997 in the low nitrogen treatment. Biomass production of this accession was significantly higher than the selected Pueblo, Colorado accession in both years in the low nitrogen treatment $(\mathrm{p}<0.05)$. Results indicate that the Pueblo, Colorado accession is the poorest competitor with cheatgrass when compared to the other squirreltail accessions tested.

\section{Discussion}

Since biomass production of cheatgrass was not affected significantly when grown with squirreltail accessions in the high nitrogen treatment, this indicates that nitrogen was not a limiting resource. In contrast, in the lower 


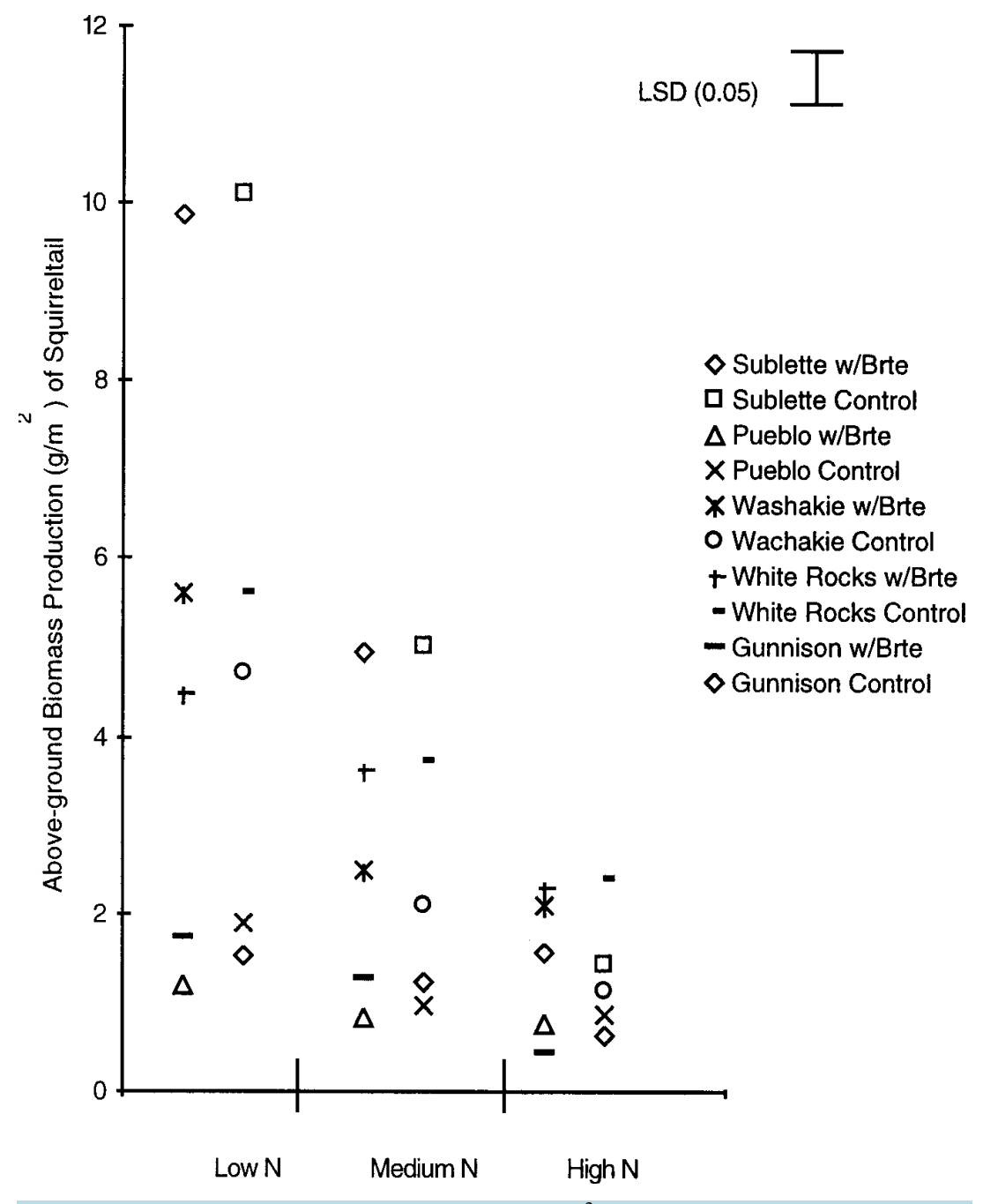

Figure 3. Above-ground biomass production $\left(\mathrm{g} \cdot \mathrm{m}^{-2}\right)$ of 5 squirreltail accessions when grown alone (Control) or with cheatgrass (w/Brte) in a Low, Medium and High nitrogen treatment in 1996.

nitrogen treatments cheatgrass biomass production did decrease indicating that squirreltail is better able to compete with cheatgrass in areas where nitrogen availability is more limiting. When brome species received nitrogen pulses, Bilbrough and Caldwell [21] found that there was increased tiller production and increased above-ground biomass production, indicating that they are good competitors for available nitrogen. Bazzaz [3] has shown that nitrogen can be limiting in arid and semiarid ecosystems. Since some squirreltail accessions tested performed better than cheatgrass at lower nitrogen levels, some squirreltail accessions should be more competitive than cheatgrass in arid and semiarid areas where low nitrogen levels are present. McLendon and Redente [7], and McLendon and Redente [8] similarly found that cheatgrass and other annuals were replaced over time as nitrogen became even more limiting.

Even though squirreltail is an early- to mid-seral species [13], it is apparently not able to utilize large amounts of available nitrogen as readily as cheatgrass. Squirreltail does, have the ability to utilize available nitrogen along an increasing gradient. This indicates that squirreltail may be able to invade into cheatgrass, in areas of low nitrogen availability. In this study, squirreltail was able to establish in all 3 nitrogen treatments which indicates that it may be possible for squirreltail to replace cheatgrass in some areas regardless of the amount of nitrogen. Insufficient data is available to determine if the squirreltail seedlings that established in nitrogen treatments were able to persist.

Results among the squirreltail accessions varied supporting Clary's study [14] which showed that ecotypic 


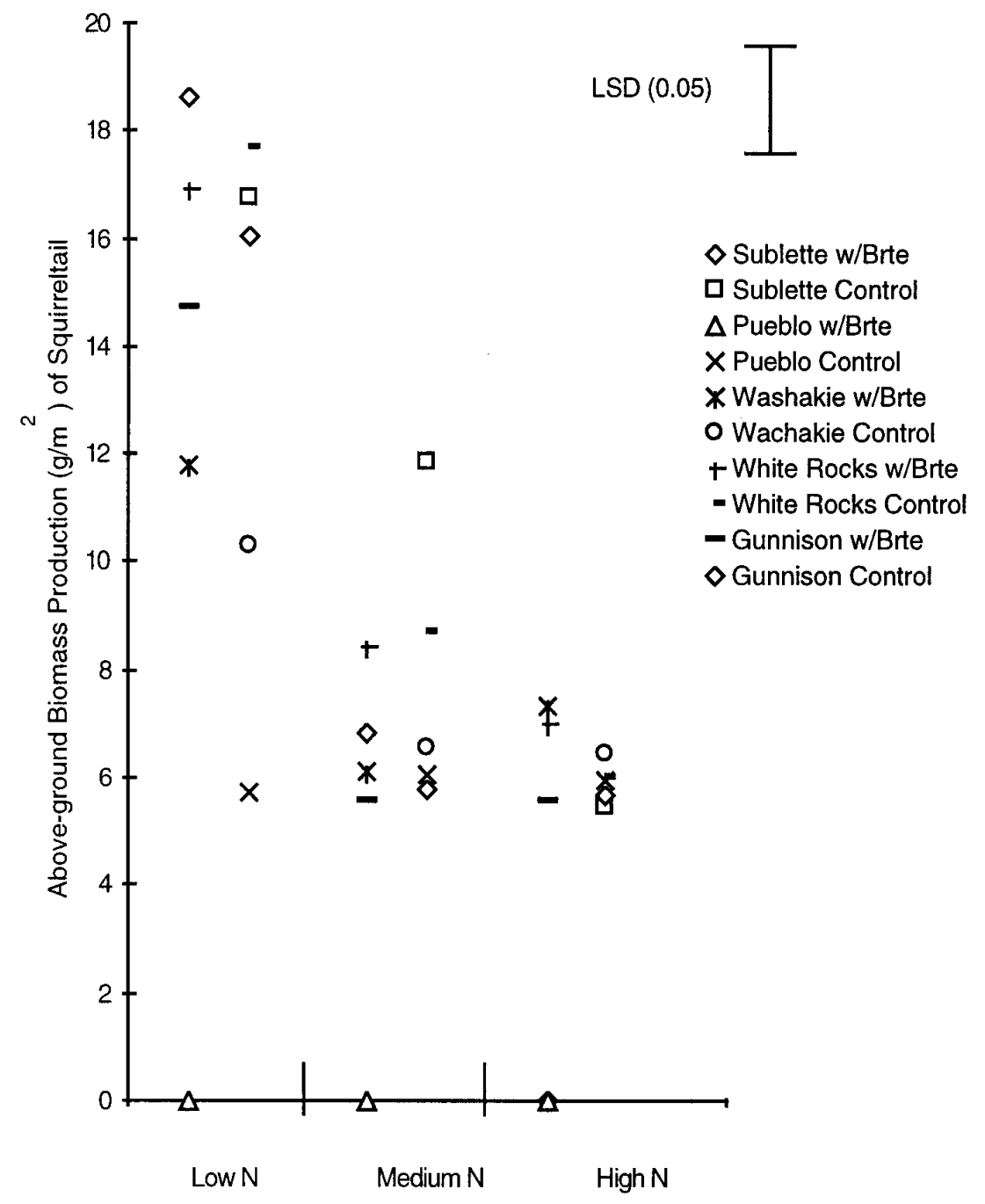

Figure 4. Above-ground biomass production $\left(\mathrm{g} \cdot \mathrm{m}^{-2}\right)$ of 5 squirreltail accessions when grown alone (Control) or with cheatgrass (w/Brte) in a Low, Medium and High nitrogen treatment in 1997.

variation exists in squirreltail. The ability of squirreltail to decrease cheatgrass biomass production varied significantly by the nitrogen gradient in the soil as well as among squirreltail accessions. Variations in the squirreltail accessions include the ability to compete with cheatgrass with nitrogen as a limiting factor, the ability to decrease cheatgrass biomass production, and the ability to increase or maintain its own biomass production in the presence of cheatgrass.

\section{Management Implications}

Nitrogen availability is important in squirreltail and cheatgrass production, and in the competitive affects between these two early seral species. In soils where nitrogen is not limiting, cheatgrass is the better competitor. When nitrogen is limiting, the ability of some accessions of squirreltail to compete with cheatgrass is enhanced.

Results from this study suggest important implications for rangeland rehabilitation. When planting squirreltail into cheatgrass dominated ranges, it is important to plant in soils that are limited in nitrogen, or limit the available nitrogen if possible. Squirreltail seed source selection should add to success in rangeland plantings. Seeds, from White Rocks, Tooele County, Utah, Sublette County, Wyoming, and Gunnison, Sanpete County, Utah are likely to perform better than those from Washakie County, Wyoming or Pueblo, Colorado when planted into cheatgrass in the environment tested. 


\section{Funding}

Research was funded in part by Utah State Department of Agriculture.

\section{References}

[1] Tilman, G.D. (1982) Resource Competition and Community Structure, Monographs in Population Biology-17. Princeton University Press, Princeton.

[2] Parish, J.A.D. and Bazzaz, F.A. (1985) Ontogenetic Niche Shifts in Old-Field Annuals. Ecology, 66, 1296-1302. http://dx.doi.org/10.2307/1939182

[3] Bazzaz, F.A. (1979) The Physiological Ecology of Plant Succession. Annual Review of Ecological Systematics, 10, 351-371. http://dx.doi.org/10.1146/annurev.es.10.110179.002031

[4] Berendse, B., Oudhof, H. and Bol, J. (1987) A Comparative Study on Nutrient Cycling in Wet Heathland Ecosystems I. Litter Production and Nutrient Loss from the Plant. Oecologia, 74, 174-184. http://dx.doi.org/10.1007/BF00379357

[5] Aerts, R. and Berendse, F. (1988) The Effect of Increased Nutrient Availability on Vegetation Dynamics in Wet Heathlands. Vegetation, 76, 63-69.

[6] Chapin, F. (1988) Ecological Aspects of Plant Nutrition. In: Tinker, P. B. and Lauchli, A., Eds., Advances in Plant Nutrition, Vol. 3, Praeger Publishers, New York, 161-191.

[7] McLendon, T. and Redente, E.F. (1991) Nitrogen and Phosphorus Effects on Secondary Succession Dynamics on a Semi-Arid Sagebrush Site. Ecology, 72, 2016-2024. http://dx.doi.org/10.2307/1941556

[8] McLendon, T. and Redente, E.F. (1992) Effects of Nitrogen Limitation on Species Replacement Dynamics during Early Secondary Succession on a Semiarid Sagebrush Site. Oecologia, 91, 312-317. http://dx.doi.org/10.1007/BF00317618

[9] Fredrick, B.A. and Klein, D.A. (1994) Nitrogen Effects on Rhizosphere Processes of Range Grasses from Different Successional Seres. Plant and Soil, 161, 241-250. http://dx.doi.org/10.1007/BF00046395

[10] Richard, C.E. and Redente, E.F. (1995) Nitrogen and Phosphorus Effects on Blue Grama and Buffalograss Interactions. Journal of Range Management, 48, 417-422. http://dx.doi.org/10.2307/4002245

[11] Hunt, H.W., Ingham, E.R., Coleman, D.C., Elliott, E.T. and Read, C.P.P. (1988) Nitrogen Limitation of Production and Decomposition in Prairie, Mountain Meadow, and Pine Forest. Ecology, 69, 1009-1016. http://dx.doi.org/10.2307/1941256

[12] Lamb, D. (1980) Soil Nitrogen Mineralization in a Secondary Rain Forest Succession. Oecologia, 47, 257-263. http://dx.doi.org/10.1007/BF00346829

[13] Monsen, S.B., Stevens, R. and Shaw, N.L. (2004) Restoring Western Ranges and Wildlands. General Technical Report, United States Department of Agriculture, Forest Service, Rocky Mountain Research Station, Fort Collins.

[14] Clary, W.P. (1975) Ecotypic Adaptation in Sitanion hystrix. Ecology, 56, 1407-1415. http://dx.doi.org/10.2307/1934707

[15] Stevens, A.R. (1997) Squirreltail (Elymus elymoides) Establishment and Competition with Cheatgrass (Bromus tectorum). Ph.D. Dissertation, Brigham Young University, Provo.

[16] DeCatanzaro, J.B. and Beauchamp, E.G. (1985) The Effect of Some Carbon Substrates on Denitrification Rates and Carbon Utilization in Soil. Biology and Fertility of Soils, 1, 183-187.

[17] Beauchamp, E., Trevors, J.T. and Paul, J.W. (1989) Carbon Sources for Bacterial Denitrification. Advances in Soil Science, 10, 113-142. http://dx.doi.org/10.1007/978-1-4613-8847-0_3

[18] Swenson, J.L., Beckstrand, D., Erickson, D.T., McKinley, C., Shiozaki, J.J. and Tew, R. (1970) Soil Survey of Sanpete Valley Area, Utah. United States Department of Agriculture-Soil Conservation Service, Salt Lake City.

[19] Mack, R.N. (1981) Invasion of Bromus tectorum L. into Western North America: An Ecological Chronicle. Agro-Ecosystems, 7, 145-165. http://dx.doi.org/10.1016/0304-3746(81)90027-5

[20] Freed, R.D. (1985) MSTAT-C Statistical Package, Version 2.0.0. Crop and Soil Science Department, Michigan State University, East Lansing.

[21] Bilbrough, C.J. and Caldwell, M.M. (1997) Exploitation of Springtime Ephemeral N Pulses by Six Great Basin Plant Species. Ecology, 78, 231-243. 